\title{
Status and Trends of the Ferruginous Duck's (Aythya nyroca) Wintering Population in Morocco: Analysis of 35 Years of Winter Census Data (1983-2017)
}

\author{
Asmaâ Ouassou $\mathbb{D}^{1},{ }^{1}$ Mohamed Dakki, ${ }^{1}$ Saïd Lahrouz, ${ }^{2}$ \\ Mohammed Aziz El Agbani, ${ }^{1}$ and Abdeljebbar Qninba ${ }^{1}$ \\ ${ }^{1}$ Mohammed V University in Rabat, Scientific Institute, Research Team on the Management of Wetlands, Geo-Biodiversity and \\ Natural Patrimony Laboratory, Avenue Ibn Battota, B.P. 703, Agdal, 10106 Rabat, Morocco \\ ${ }^{2}$ GREPOM/BirdLife Morocco, Scientific Institute, Av. Ibn Battota, B.P. 703, Agdal, 10106 Rabat, Morocco \\ Correspondence should be addressed to Asmaâ Ouassou; asmaa.ouassou@gmail.com
}

Received 21 May 2018; Accepted 31 August 2018; Published 2 October 2018

Academic Editor: Marco Cucco

Copyright (C) 2018 Asmaâ Ouassou et al. This is an open access article distributed under the Creative Commons Attribution License, which permits unrestricted use, distribution, and reproduction in any medium, provided the original work is properly cited.

\begin{abstract}
The Ferruginous duck is a winter visitor and breeding resident in Morocco. The species breeds regularly in several coastal and inland wetlands, with remarkable numbers in some marshlands (Sidi Boughaba, Fouwarate, Bargha, Bas Loukkos, etc.). This duck is listed as near threatened in the IUCN Red List, and its populations have been in decline in many European countries. In Morocco, the national wintering population has known, during the last decade, a strong increase, in both its numbers (from tens to thousands of individuals) and distribution area (from a couple of sites to more than 21 wetlands). The North-West region of Morocco has been hosting regularly, during the last decade, between 31 and $91 \%$ of the Moroccan wintering population, which is mainly concentrated in two marshlands: Merja de Fouwarate and Merja de Sidi Boughaba. A small reservoir, Barrage Hassar, recently created in the Centre-Atlantic region, has also been, in recent years, one of the most important wintering sites of the species. 15 wetlands have hosted, at least once during the last decade, more than $1 \%$ of the regional population of "West Mediterranean/North and West Africa". This work is an important step to a better knowledge of the Ferruginous duck's population. This knowledge is the basis for adopting adequate measures for the conservation of the species at the national and international level.
\end{abstract}

\section{Introduction}

The Ferruginous Duck Aythya nyroca (Güldenstädt, 1770) is a winter visitor and a breeding resident in Morocco [1, 2]; it winters regularly in the Northern part of the country, usually in small numbers, in comparison with Tropical Africa [2].

Recent breeding data show that the species breeds regularly in Marais du bas Loukkos [3], Marais de l'wad Smir [4], Marais de Wad El Maleh [5], Merja de Sidi Boughaba [6], and Merja de Wad Fouwarate [7]. In addition, unpublished data have been collected also from Barrage El Mehraz, near Fès city, and from a small marshland in Walidia. Nesting signs could be observed from late March till July, with a peak in egg lying in May and June [7, 8].

In Europe, the Ferruginous duck prefers shallow freshwater wetlands [9], generally rich in emergent vegetation [1012], but it can occupy coastal ecosystems [13]. In Morocco, this species is most commonly found in marshes and lakes with emergent plants (mainly Typha, Phragmites, Scirpus, Sparganium, Cladium, and Carex) that create safe nesting areas for the species [14].

According to recent data [15], the Ferruginous duck's global population is estimated at 180.700-238.000 individuals. The 'West Mediterranean/North \& West Africa" region, to which the Moroccan population belongs, holds 5.700-6.300 individuals. The species is indeed classified as "near threatened", both in the IUCN Red List and on the CMS/AEWA Appendices (1, A-la, and 1c), knowing that its global population is still declining [13]. This decline is mainly linked to habitat loss, particularly due to the destruction of freshwater bodies with dense vegetation $[10,11,16]$. An international action plan has been developed, aiming to conserve the species [17]. 
In Morocco, the Ferruginous duck, previously represented by very few individuals permitting to classify it as endangered, became recently more common, but still in a vulnerable situation, knowing that its habitats are relatively fragile.

This study presents an analysis of the winter census data of the Ferruginous duck during the 1983-2017 period in Morocco. This census was made in the context of the International Waterbird Census (IWC), conducted in Morocco regularly since 1983, in close coordination between the Scientific Institute (Study Centre of Bird Migration), GREPOM (Research Group for Bird Protection in Morocco), and the Medwaterbirds Network [18]. We will focus in this work on spatiotemporal patterns of the species and its best wintering sites.

\section{Materials and Methods}

This study is based on the data collated from the national information system used to manage the International Waterbird Census in Morocco. These data are compiled in annual tables with a simple format (sites x species) that could be used to calculate average numbers and trends in time.

To determine the national population size, only recent data (2008-2017) are used. This parameter is estimated by the national average of the total wintering numbers, which is obtained by summing the average of the annual numbers in each site. This estimation is more precise than the average of the annual total of numbers counted in the country. These same data are used to illustrate the winter distribution of the species, using ArcMap tools.

The analysis of the specific data to each site permitted to identify wetlands verifying the $6^{\text {th }}$ Ramsar criterion, considering that a site verifies this criterion for the Ferruginous duck, when this species reaches the $1 \%$ of its regional population, at least once during the last decade.

The trend pattern of the national wintering population was analyzed for the 35 years (1983-2017), during which the IWC was regularly conducted. This analysis was undertaken using TRIM (TRends and Indices for Monitoring Data), a freeware program, developed by Statistics Netherlands in the framework of wildlife statistics. This program analyzes time series of counts, using log linear Poisson regression, and produces estimates of yearly indices and trends. This tool deals with several difficulties inherent to monitoring data, especially missing values and undersampling of certain sites compared to others [19]. In Morocco, many sites were not regularly visited, mainly before 1991, either due to difficult access (e.g., heavy snowfall) or simply due to a lack in logistical capacity.

The results of the trend analyses are translated into six possible trends categories: (1) strong increase (significantly more than $5 \%$ per year), (2) moderate increase (not significantly more than 5\%), (3) stable (no significant increase or decline, and it is certain that trends are less than $5 \%$ per year), (4) uncertain (no significant increase or decline, but not certain if trends are less than $5 \%$ per year), (5) moderate decline (not significantly more than $5 \%$ per year), and (6)

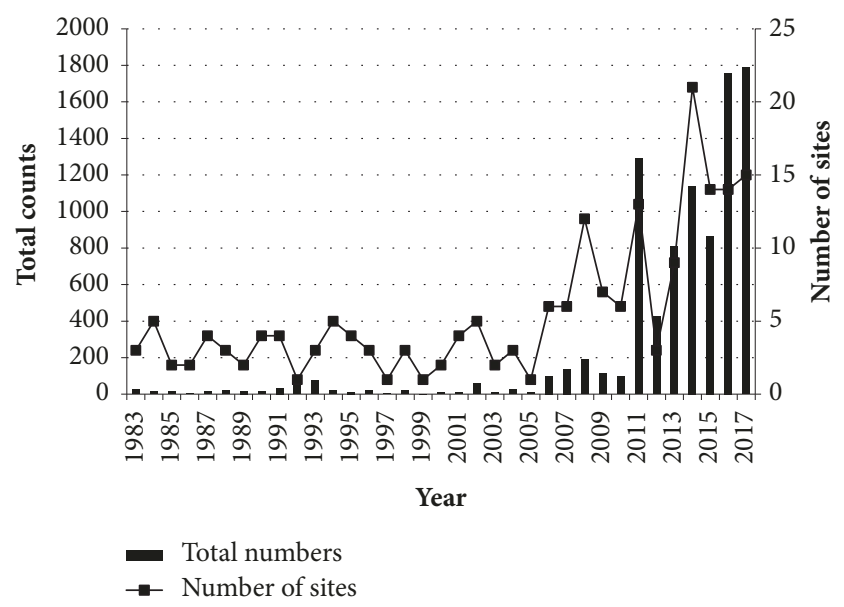

FIGURE 1: Evolution of the total winter counts and the number of wetlands where the Ferruginous duck has been observed in Morocco during the period 1983-2017.

steep decline (significantly more than $5 \%$ per year, meaning a halving in abundance within 15 years).

\section{Results}

3.1. Population Size. The 35-year counts (See Table S1 in the Supplementary Material for the counts raw dataset) show an increase of the national population size, as well as the number of wintering sites of the Ferruginous duck (Figure 1). Until 2008, this number varied from year to year, between 2 and 6 , while the total number of wintering sites was limited to 12 wetlands. This number increased progressively and reached its maximum level (21 wintering sites) in 2014. The wintering numbers increased particularly during the 20112017 period, where annual totals varied between 400 and 1.800, the lowest number being in 2012 (about 400 ducks), due to an undersampling of sites, and the maximums in 2016 and 2017.

This increase in the number of the species wintering sites could be correlated to the increase in the number of sites visited, which translates an improvement in the census effort. However, this effort does not correlate with the remarkable evolution of the wintering population (from a couple to thousands of individuals). This is well illustrated by the case of the 2014 census, where visited sites reached their highest number (115 wetlands), but the wintering Ferruginous ducks were not at their highest numbers and their distribution did not exceed $18 \%$ of the total visited sites.

3.2. Population Trend. The trend pattern of the wintering population was analyzed by the TRIM software over the last 35 years (1983-2017). This model was applied to all the sites where wintering Ferruginous ducks were recorded. The total number of counts is 1.820, and 953 counts were missing. In fact, several sites are irregularly visited, some of them being visited only once during the last 35 years. Moreover, some wetlands (mainly dams) have only been recently included in the national network of the winter census program. 


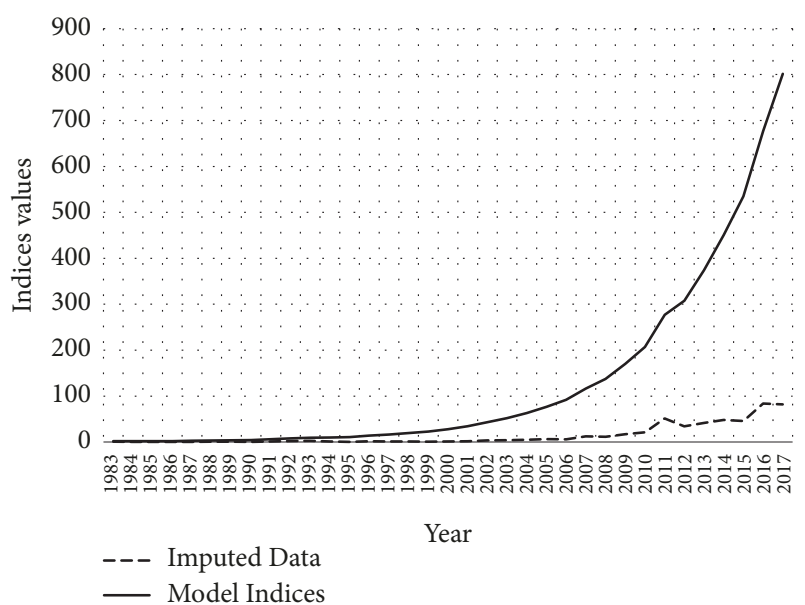

FIGURE 2: Linear trend of the Ferruginous duck's wintering population (TRIM analysis).

The result of this analysis has shown a recent strong increase of the wintering population of the species (Figure 2). However, more than $10 \%$ of the wintering individuals were hosted by two sites: Merja de Wad Fouwarate and Merja de Sidi Boughaba, located near Kenitra city (North-West of Morocco).

3.3. Winter Distribution. During the first IWC (International Waterbirds Census) organized in Morocco (on 1983), the Ferruginous duck was reported from three sites in distinct regions, with less than 20 individuals each: Barrage Mechra' Hommadi in the North-East, Dayet 'Awa in the Middle Atlas, and Embouchure de l'wad Massa in the South-West. Then, the wintering population showed, throughout the years, a progressive expansion to other sites, reaching 52 wetlands in 2017.

However, wintering Ferruginous ducks are generally concentrated in the Northern part of Morocco, especially the North-West region, which hosted, during the last ten years, between 31 and $91 \%$ of the national population (Figure 3). The Centre-Atlantic and the North-East region come in second rank, since they have hosted up to $39 \%$ of the wintering individuals, followed by the Atlas and South region, which hold around $15 \%$ of the national population and exceptionally, 49\% for the Atlas region in 2008 (thanks to Dayet 'Awa), and $64 \%$ for the South region in 2010 (thanks to Barrage Zelmou).

Highest concentrations are observed in marshlands on the Atlantic and Mediterranean littorals (Figure 4), but also in some inland lakes and dams (in Middle Atlas, Saïss plain, Centre-Atlantic, and North-East). Substantial numbers could be counted in some river mouths and lagoons.

Five wetlands have hosted $78 \%$ of the national wintering population during the last decade (Table 1): Merja de Wad Fouwarate, Merja de Sidi Boughaba, Barrage Hassar, Barrage Mohamed V, and Dayet 'Awa.

Three dams are visited by significant numbers of wintering individuals but with less regularity:

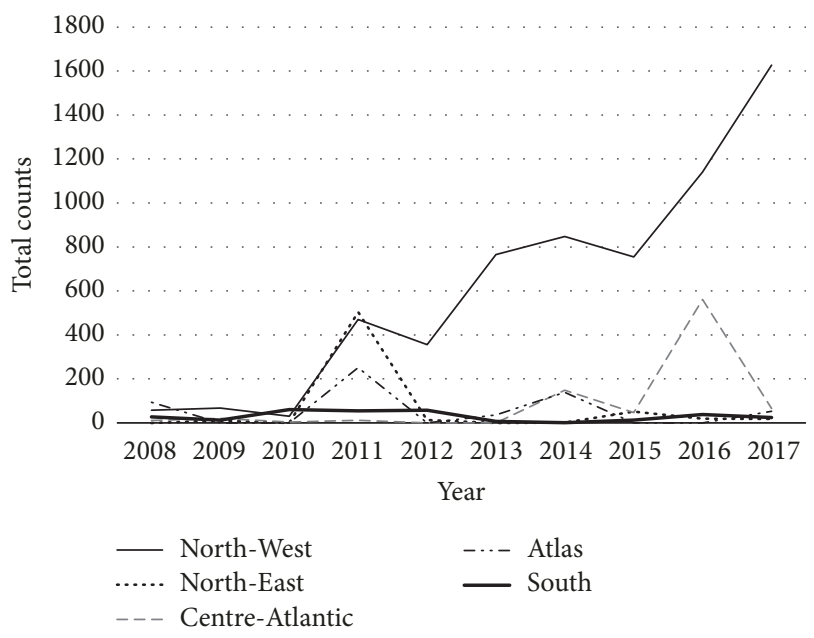

FIGURE 3: Evolution of the Ferruginous duck's total numbers by region during the last decade.

(i) Barrage Mohammed $V$, where the first occurrence of the Ferruginous duck has been reported in 2007, with a maximum of 400 individuals observed in 2011

(ii) Barrage Al Wahda, where census started only recently, cumulating three visits (2014 to 2016), and which could be a potentially important wintering site for the species, since 99 wintering individuals have been observed in 2016

(iii) Barrage Hassar, in the Centre-Atlantic region, which has been visited for the first time in 2014 and could host more than 500 wintering individuals

Based on recent data, the most regular wintering sites in Morocco, where the Ferruginous duck has been reported at least $80 \%$ of the time (Table 1), are Merja de Sidi Boughaba, Barrage Zelmou, Merja de Wad Fouwarate, Dayet 'Awa, and Marais du bas Loukkos.

The presence of the species in other sites can be irregular (such as the case for Embouchure de l'wad Massa, Merja Bargha, etc.), rare, or exceptional/accidental (e.g., Baie d'AdDakhla, where only one individual has been observed in 1995).

3.4. Sites Verifying the $6^{\text {th }}$ Ramsar Criterion. To apply the $6^{\text {th }}$ Ramsar criterion to the Ferruginous duck's wintering data, the threshold used is 25 birds, corresponding to $1 \%$ of the regional population of "West Mediterranean/North \& West Africa" [15].

During the last ten years (2008-2017), this threshold has been exceeded at least once in 15 wetlands (Table 2). Merja de Wad Fouwarate and Merja de Sidi Boughaba, in the North-West region, come first by verifying this criterion, respectively, seven and six winters. Another lake, Dayet 'Awa, in the Middle Atlas, reached this threshold three times. Three artificial reservoirs also verify this criterion 3-4 times; two of them, Barrage Zelmou and Barrage Mohammed V, are in the North-East of Morocco and the third, Barrage Hassar, is in the North-West region. The remaining wetlands have verified this criterion only $1-2$ winters during the last 10 winter counts. 


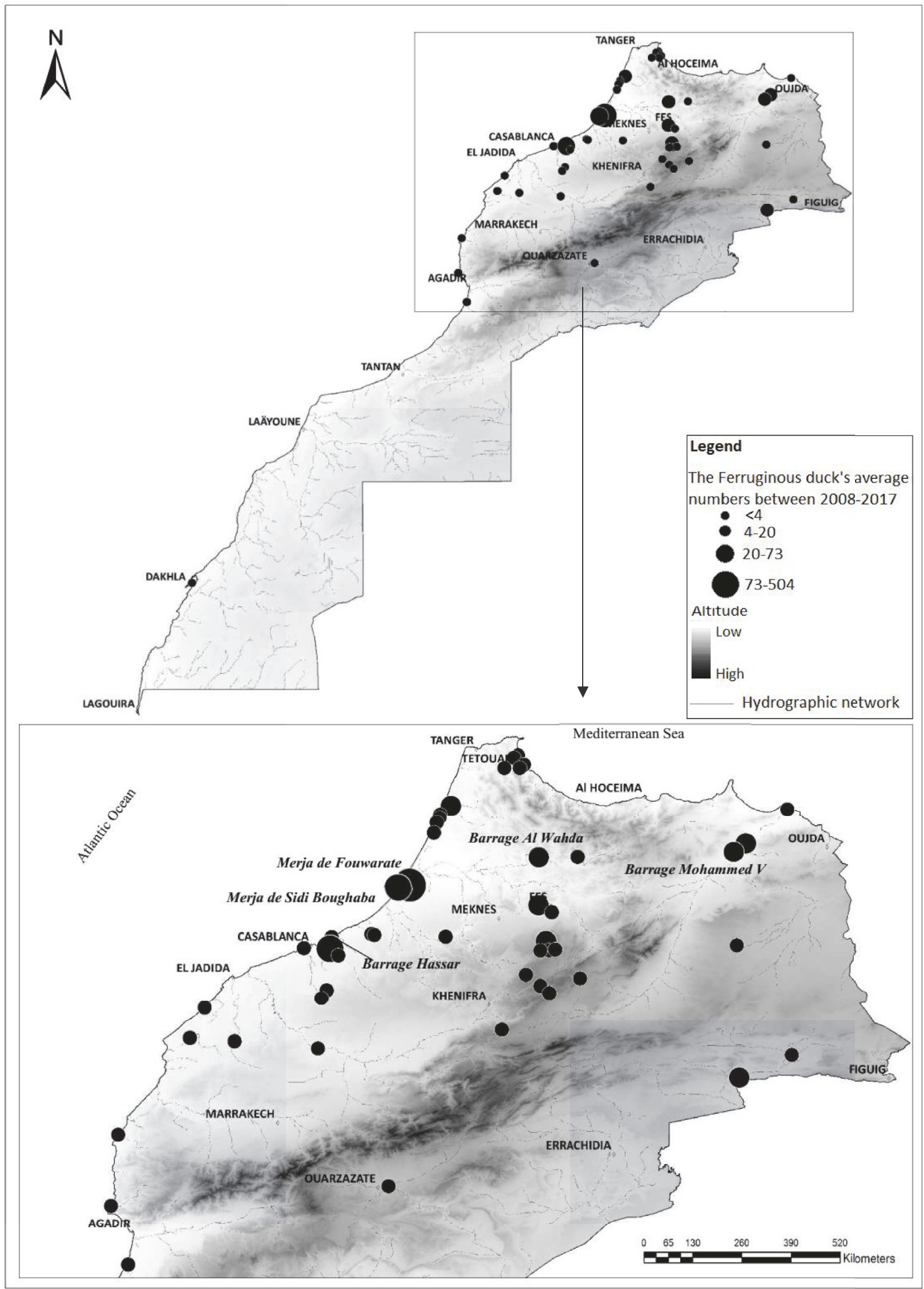

FIGURE 4: Distribution map of the Ferruginous duck's wintering population in Morocco. 
TABLE 1: Most important wintering sites of the Ferruginous duck.

\begin{tabular}{|c|c|c|c|c|c|}
\hline Site name & $\begin{array}{c}\text { Average } \\
\text { 2008-2017 }\end{array}$ & Maximum & Occurrence & Number of censuses & $1^{\text {st }}$ census \\
\hline Merja de l'wad Fouwarate & 504 & 1200 & 8 & 19 & 1990 \\
\hline Merja de Sidi Bou Ghaba & 221 & 400 & 21 & 32 & 1983 \\
\hline Barrage Hassar & 174 & 516 & 4 & 4 & 2014 \\
\hline Barrage Mohammed V & 73 & 400 & 4 & 24 & 1984 \\
\hline Dayet 'Awa & 53 & 195 & 8 & 29 & 1983 \\
\hline Barrage Al Wahda & 33 & 99 & 1 & 3 & 2014 \\
\hline Barrage Zelmou & 26 & 58 & 9 & 10 & 2007 \\
\hline Barrage Mechra' Hommadi & 25 & 76 & 3 & 13 & 1983 \\
\hline Plan d'eau de Dwiyate & 22 & 22 & 5 & 15 & 1983 \\
\hline Marais du bas Loukkos & 21 & 68 & 20 & 34 & 1984 \\
\hline Aguelmam Afennourir & 19 & 56 & 3 & 26 & 1983 \\
\hline Merja Bargha & 16 & 63 & 9 & 26 & 1988 \\
\hline Aguelmam N'Tifounassine & 14 & 30 & 2 & 21 & 1987 \\
\hline Réserve royale Aïn Sferjla & 11 & 15 & 2 & 2 & 2009 \\
\hline Barrage Al Himer & 10 & 10 & 1 & 1 & 2014 \\
\hline Dayet Ifrah & 9 & 33 & 3 & 29 & 1983 \\
\hline Dayet Hachlaf & 9 & 24 & 3 & 7 & 1997 \\
\hline Daya Bennejma & 9 & 17 & 1 & 2 & 2016 \\
\hline $\begin{array}{l}\text { Lagunes de Sidi } \\
\text { Moussa-Walidia }\end{array}$ & 7 & 44 & 5 & 33 & 1983 \\
\hline Marais de Wad Al Maleh & 7 & 12 & 4 & 6 & 2001 \\
\hline
\end{tabular}

TABLE 2: Wetlands hosting, at least once, more than $1 \%$ of the Ferruginous duck's regional population.

\begin{tabular}{|c|c|c|c|c|c|c|c|c|c|c|c|}
\hline Site name $\backslash$ Years & 2008 & 2009 & 2010 & 2011 & 2012 & 2013 & 2014 & 2015 & 2016 & 2017 & $1 \% \mathrm{RP} *$ \\
\hline Merja de l'wad Fouwarate & & & & 324 & 356 & 680 & 450 & 386 & 634 & 1200 & 7 \\
\hline Merja de Sidi Bou Ghaba & 22 & & & 83 & & 72 & 250 & 320 & 400 & 400 & 6 \\
\hline Barrage Zelmou & 9 & 5 & 57 & 52 & 58 & 7 & & 5 & 20 & 25 & 4 \\
\hline Barrage Mohammed V & & 5 & & 400 & & & & 35 & & & 2 \\
\hline Barrage Hassar & & & & & & & 124 & 45 & 516 & 12 & 3 \\
\hline Dayet 'Awa & 65 & & & 195 & & 2 & 46 & & & 7 & 3 \\
\hline Marais du bas Loukkos & 14 & 68 & 13 & & & 5 & 61 & 24 & 6 & 19 & 2 \\
\hline Merja Bargha & & & & 50 & & 8 & 63 & 9 & & & 2 \\
\hline Barrage Al Wahda & & & & & & & & & 99 & & 2 \\
\hline Aguelmam N'Tifounassine & & & & & & 30 & 27 & & & & 2 \\
\hline Barrage Mechra' Hommadi & & & & 76 & & & & & & & 1 \\
\hline Lagunes de Sidi Moussa-Walidia & & & & & & & & 2 & 10 & 44 & 1 \\
\hline Côte et Archipel d'Essawira & & & & & & & & & 35 & 4 & 1 \\
\hline Dayet Ifrah & & & & & & & 33 & & & 22 & 1 \\
\hline Aguelmam Afennourir & 21 & & & 56 & & & 16 & & & & 1 \\
\hline No. of sites verifying the $1 \%$ threshold & 1 & 1 & 1 & 8 & 2 & 3 & 8 & 4 & 5 & 4 & \\
\hline
\end{tabular}

* Number of times the $1 \%$ of the Regional Population of the species ("West Mediterranean/North \& West Africa") (25 individuals) has been reached or exceeded.

Some Ferruginous ducks winter in several wetlands that already have national or international conservation status (Table 3). Thereby, 15 wetlands are Important Bird and Biodiversity Areas (IBAs), while 14 are Ramsar sites and two others are candidates to this status. Moreover, 25 wetlands have a national conservation status known as SIBE (Sites of Biological and Ecologic Interest). Among the 28 wetlands of national and/or international importance, 9 of 
TABLE 3: Conservation statuses of the Ferruginous duck's wintering sites.

\begin{tabular}{|c|c|c|c|c|c|}
\hline Site name & Types of habitat & Region & Ramsar status & SIBE $^{1}$ & IBA $^{2}$ \\
\hline Marais de l'wad Smir & Marshland & North-West & Candidate & $\mathrm{X}$ & \\
\hline Barrage de Smir & Artificial reservoir / Dam & North-West & Candidate & & \\
\hline Marais du bas Loukkos & Marshland & North-West & $\mathrm{X}$ & $\mathrm{X}$ & $\mathrm{X}$ \\
\hline Merja des Wlad Skher & Marshland & North-West & & $\mathrm{X}$ & \\
\hline Merja Bargha & Marshland & North-West & & $\mathrm{X}$ & $\mathrm{X}$ \\
\hline Merja Al Halloufa & Marshland & North-West & & $\mathrm{X}$ & $\mathrm{X}$ \\
\hline Merja Zerga & Marshland & North-West & $\mathrm{X}$ & $\mathrm{X}$ & $\mathrm{X}$ \\
\hline Merja de l'wad Fouwarate & Marshland & North-West & $\mathrm{X}$ & $\mathrm{X}$ & \\
\hline Merja de Sidi Bou Ghaba & Marshland & North-West & $\mathrm{X}$ & $\mathrm{X}$ & $\mathrm{X}$ \\
\hline Plan d'eau de Dwiyate & Lake & North-West & & & $\mathrm{X}$ \\
\hline Embouchure de l'wad Malwiya & River mouth & North-East & $\mathrm{X}$ & $\mathrm{X}$ & $\mathrm{X}$ \\
\hline Barrage Mohammed V & Artificial reservoir / Dam & North-East & $\mathrm{X}$ & $\mathrm{X}$ & $\mathrm{X}$ \\
\hline Marais de Wad Al Maleh & Marshland & Centre-Atlantic & $\mathrm{X}$ & & \\
\hline Barrage de l'wad Al Mellah* & Artificial reservoir / Dam & Centre-Atlantic & & $\mathrm{X}$ & \\
\hline Lagunes de Sidi Moussa-Walidia & Lagoon/Marshland & Centre-Atlantic & $\mathrm{X}$ & $\mathrm{X}$ & \\
\hline Barrage Al Massira & Artificial reservoir / Dam & Centre-Atlantic & $\mathrm{X}$ & $\mathrm{X}$ & $\mathrm{X}$ \\
\hline Côte et Archipel d'Essawira & Coastal wetland & Centre-Atlantic & $\mathrm{X}$ & $\mathrm{X}$ & $\mathrm{X}$ \\
\hline Dayet 'Awa & Inland lake & Atlas & & $\mathrm{X}$ & \\
\hline Dayet Ifrah & Inland lake & Atlas & & $\mathrm{X}$ & \\
\hline Plan d'eau de Zerrouqa & Inland lake & Atlas & & $\mathrm{X}$ & \\
\hline Aguelmam Afennourir & Inland lake & Atlas & $\mathrm{X}$ & $\mathrm{X}$ & $\mathrm{X}$ \\
\hline Aguelmam N’Tifounassine & Inland lake & Atlas & $\mathrm{X}$ & $\mathrm{X}$ & \\
\hline Aguelmams Sidi Ali-Ta’nzoult & Inland lake & Atlas & & $\mathrm{X}$ & $\mathrm{X}$ \\
\hline Aguelmam Abekhane & Inland lake & Atlas & & $\mathrm{X}$ & \\
\hline Barrage Al Mansour Ad-Dahbi & Artificial reservoir / Dam & South & & $\mathrm{X}$ & $\mathrm{X}$ \\
\hline Embouchure de l'wad Tamri* & River mouth & South & & $\mathrm{X}$ & $\mathrm{X}$ \\
\hline Embouchure de l'wad Massa & River mouth & South & $\mathrm{X}$ & $\mathrm{X}$ & \\
\hline Baie d’Ad-Dakhla* & Bay & South & $\mathrm{X}$ & $\mathrm{X}$ & $\mathrm{X}$ \\
\hline
\end{tabular}

them beneficiate from all three national and international conservation statuses and 10 are protected by at least two conservation statuses.

\section{Discussion}

The main purpose of this paper was to provide current and historical statuses of the wintering population of the Ferruginous duck in Morocco. The available data of winter census, from 1983 to 2017, has shown a strong increase in numbers of both wintering birds and sites.

However, the precise global trend of the species remains unknown [13], but the general profile of the population shows local decline, especially in Europe. Data on Asian populations suggest evidence of decline but is sometimes contradictory [13]. Therefore, the overall population is considered as declining at moderate rates as a precautionary measure, and the species is still classified as "near threatened" in the IUCN Red List [13].

The Moroccan population of the Ferruginous duck shows an increase in its wintering and breeding individuals. Our data is consistent with the most recent trend analyses of the Ferruginous duck's population, specifically in the "West Mediterranean/North \& West Africa" region. In fact, after a strong decline at both international and regional levels, the regional population of this species has grown to reach the recent estimate of 5.700-6.300 individuals [15]. Although North Africa represents an important stopover for the species, it generally hosts small numbers, compared to East Africa (e.g., Sudan, Ethiopia), which is the main wintering area for this duck [20]. Nevertheless, the species has been expanding to Tunisia [21, 22], where up to 80 pairs have been reported in a dozen wetlands [21, 23] and increasing numbers have been recorded during the wintering period [24]. Furthermore, Algerian wetlands are the most important breeding and wintering sites for the species in North Africa. They host its highest concentrations $[8,21,25-30]$, especially in the Northeast region, where wintering numbers fluctuate between 1500 and 3500 individuals [26] and more than 700 pairs breed at Lake Tonga alone [21]. Overall, the species population in Algeria seems to be improving [25, 30, 31], even though it is not the case in some Algerian wetlands [32], 
where anthropogenic pressures are negatively impacting its population $[29,33]$.

The Ferruginous duck faces indeed many threats that are mainly related to the destruction of wetlands habitats, especially the ones with dense vegetation $[10,11,16,17]$, and changes in water regimen and levels. Other factors contributing to the decline in the global species populations are related to the introduction of nonnative species and predators [17]. The increased drought due to climate change can also pose a threat $[16,17,34]$, as its breeding depends on sufficient water levels, which can play a role in maintaining feeding areas for ducks and potentially decreasing the predation rate of nests $[8,14,29,35]$. Moreover, hunting represents a serious threat to the species, especially during the autumn passage and on its wintering areas in East Africa (e.g., Sudan) [11, 36]. Additionally, significant numbers are illegally killed each year, especially in Serbia, Libya, and Croatia [37].

All these threats faced by the Ferruginous duck make it vulnerable and contribute to the general decline of its population. This could potentially point out to a possible decline or possible shift in its European breeding populations.

Multiple hypotheses could explain the increase in wintering populations in Morocco.

One hypothesis could be related to the hosting capacity of national wetlands and the moderate meteorological conditions in Morocco, offering the species shelter and good feeding grounds. In fact, contrary to the IPCC (Intergovernmental Panel on Climate Change) models predicting lower rainfall and increased aridity, there is a gradual return to wetter conditions in Morocco since 2008 [38], contributing to good water levels. Indeed, the Ferruginous duck tends to occupy new areas if their climatic conditions become more wet, as it was the case for China [39].

Although the available data on the trend of breeding populations shows conflicting and fluctuating trends, according to Robinson and Hughes [17], with up to $37 \%$ of the countries where the Ferruginous duck breeds, having no estimate of population trend; another hypothesis could be related to successful conservation measures established in Europe (e.g., habitat management in Bulgaria and reintroduction schemes in Italy [40]), contributing to a possible increase in the breeding success of the species, thus in the numbers of wintering individuals.

A third hypothesis for the Ferruginous duck's Moroccan population increasing trend is the shifting of a part of its regional population to Morocco, either from the wintering population in East Africa or a part of the breeding population in Europe which became resident in the country, because of a more suitable environment.

As stated by Robinson and Hughes [17], in the International Action Plan for the Conservation of the Ferruginous duck, many data gaps on the species population remain, which could be crucial to having a better knowledge and understanding of the populations estimates and trends and thus be able to adopt and implement the right conservation measures to restore the species populations to a stable level.
4.1. Key Wintering Sites in Morocco. The distribution of the Ferruginous duck over the national territory and the sites it occupies is consistent with its preferred habitat (mainly freshwater habitats with dense vegetation).

It is mostly concentrated in the North-West region of Morocco, on the Atlantic coast. Two wetlands have hosted regularly and most frequently the highest numbers of wintering individuals: Merja de Wad Fouwarate and Merja de Sidi Boughaba. The latter is a Ramsar site since 1980 and the first one has just been classified in 2018.

Other sites have hosted high numbers of the Ferruginous duck. But for some of them, the census effort is either recent (e.g., the first census for Barrage Hassar was in 2014) or not regular. Nevertheless, we consider that the wetlands that have been hosting high numbers of the Ferruginous duck's wintering individuals (more than $1 \%$ of its regional population) and for at least 7 winters are of national importance for the species.

Identifying the key wintering sites of this threatened duck is crucial to call for appropriate conservation measures for these wetlands. In fact, even though our country has been hosting increasing numbers of the Ferruginous duck, the future of its growing population depends on the conservation of its privileged sites, which face growing threats related, especially, to habitat loss [41].

\section{Conclusion}

This study has given an overview on the recent status and population trend of the Ferruginous duck in Morocco. The species used to winter in the country, as in the rest of the Maghreb region countries, in small numbers. Nonetheless, the species has known a strong increase in its population, at the national level, over the years, as much as in its distribution, since it is also breeding in new sites.

The results obtained indicate that the three major wintering sites of the species are Merja de Wad Fouwarate, Merja de Sidi Boughaba, and Barrage Hassar. The species also winters more or less regularly in other wetlands that often host more than $1 \%$ of its regional population (15 sites in the last ten years).

This work is but a first step into a better knowledge on the Ferruginous duck's population at the national level. Future work should research the factors influencing the distribution of the species and its choice of wintering and potentially suitable breeding sites.

Concerted efforts should also be conducted to acquire more data on the species at the regional and global level, since a lot of information on the estimates and trends of its global population remains unknown or uncertain.

\section{Data Availability}

All data generated or analyzed during this study are included in this published article (and its supplementary material files).

\section{Conflicts of Interest}

The authors declare that there are no conflicts of interest regarding the publication of this paper. 


\section{Acknowledgments}

The authors would like to acknowledge the consistent efforts of the observers, national and international, who have relentlessly participated in the waterbirds winter census that has been conducted regularly in Morocco since 1983. Their commitment is the key that has contributed to a better knowledge, for the conservation of waterbirds at the national and international level. The authors greatly appreciate the moral, technical, and financial support of the Medwaterbirds Network (coordinated by la Tour du Valat) and GREPOM/BirdLife Morocco, to the national waterbirds winter census campaigns.

\section{Supplementary Materials}

Table S1: national counts of the Ferruginous duck's wintering individuals per year and per site. (Supplementary Materials)

\section{References}

[1] M. Thévenot, R. Vernon, and P. Bergier, "The Birds of Morocco," BOU, Checklist Series, 20.594 pp., ISBN 0907446 25 6, 2003.

[2] P. Bergier, M. Thévenot, A. Rihane, M. A. El Agbani, and A. Qninba, "Liste des oiseaux du Maroc. Mise à jour : mai 2017 (rév. 4.0)," Go-South, vol. 14, pp. 43-68, 2017.

[3] A. Qninba, H. Rguibi Idrissi, O. Himmi, A. Benhoussa, M. A. El Agbani, and M. Thévenot, "Nouveaux cas de nidification d'oiseaux dans le complexe de zones humides du Bas Loukkos (Nord-Ouest du Maroc)," Bulletin de l'Institut Scientifique, Rabat, Section Sciences de la Vie, vol. 30, pp. 45-50, 2008.

[4] M. A. El Agbani, A. Qninba, M. Amezian, F. Cuzin, and M. Dakki, "Le peuplement d'oiseaux d'eau du complexe des zones humides de Smir (Nord du Maroc) ; état actuel et évolution depuis les quatre dernières décennies," Bulletin de l'Institut Scientifique, Rabat, Section Sciences de la Vie, vol. 31, pp. 103110, 2009.

[5] A. Rihane, "Reproduction du Fuligule nyroca Aythya nyrocadans l'estuaire de l'Oued El Maleh, Mohammedia," Go-South Bulletin, vol. 9, pp. 155-160, 2012.

[6] I. Cherkaoui, M. Dakki, S. Lahrouz, and S. Hanane, "Dix années de suivi des Anatidés nicheurs sur le lac de Sidi Boughaba (Nord-Ouest Marocain) : Situation, tendances d'évolution et perspectives de recherche," Revue d'Ecologie (La Terre et la Vie), vol. 68, pp. 167-180, 2013.

[7] S. Lahrouz, M. Dakki, and N. Gmira, "The importance of Fouwarate marshland for wintering and breeding of the threatened ducks' populations in Morocco," Journal of Animal and Plant Sciences, vol. 13, pp. 1800-1810, 2012.

[8] A. Fouzari, F. Samraoui, A. H. Alfarhan, and B. Samraoui, "Nesting ecology of Ferruginous duck Aythya nyroca in northeastern Algeria," African Zoology, vol. 54, no. 4, pp. 299-305, 2015.

[9] D. W. Snow and C. M. Perrins, Non-Passerines, vol. 1 of The Birds of the Western Palearctic, Oxford University Press, Oxford, Uk, 1998.

[10] J. del Hoyo, A. Elliot, and J. Sargatal, Ostrich to Ducks, vol. 1 of Handbook of the Birds of the World, Lynx Editions, Barcelona, Spain, 1992.

[11] J. Kear, Species Accounts (Cairina to Mergus), vol. 2 of Ducks, geese and swans, Oxford Univ. Press, Oxford, UK, 2005.
[12] A. J. Green, "Habitat selection by the Marbled teal Marmaronetta angustirostris, Ferruginous duck Aythya nyroca and other ducks in the Göksu delta, Turkey, in summer," Revue d'Ecologie (La Terre et la Vie), vol. 53, 1998.

[13] BirdLife International, "Aythya nyroca," in The IUCN Red List of Threatened Species, 2017.

[14] S. I. Cherkaoui, N. Magri, and S. Hanane, "Factors Predicting Ramsar Site Occupancy by Threatened Waterfowl: The Case of the Marbled Teal Marmaronetta angustirostris and Ferruginous Duck Aythya nyroca in Morocco," Ardeola, vol. 63, no. 2, pp. 295-309, 2016.

[15] Wetlands International, "Waterbird Population Estimates," Retrieved from http://wpe.wetlands.org/, 2017.

[16] K. E. Vinicombe, "Identification of Ferruginous Duck and its status in Britain and Ireland," British Birds, vol. 93, no. 1, pp. 421, 2000.

[17] J. A. Robinson and B. Hughes, "International Single Species Action Plan for the Conservation of the Ferruginous Duck," CMS Technical Series No. 12 \& AEWA Technical Series No. 7, Bonn, Germany, 2006.

[18] M. S. Sayoud, H. Salhi, B. Chalabi et al., "The first coordinated trans-North African mid-winter waterbird census: The contribution of the International Waterbird Census to the conservation of waterbirds and wetlands at a biogeographical level," Biological Conservation, vol. 206, pp. 11-20, 2017.

[19] A. Van Strien, J. Pannekoek, W. Hagemeijer, and T. Verstrael, "A loglinear Poisson regression method to analyse bird monitoring data," in Bird Numbers 1995, Proceedings of the International Conference and 13th Meeting of the European Bird Census Council, A. Anselin, Ed., vol. 13, pp. 33-39, Bird Census News, Pärnu, Estonia, 2000.

[20] EGA-RAC/SPA Waterbird Census Team, Atlas of Wintering Waterbirds of Libya, 2005-2010, Imprimerie COTIM, Tunisia, 2012.

[21] S. E. Merzoug, W. A. Abda, M. Belhamra, and M. Houhamdi, "Eco-ethology of the wintering Ferruginous duck Aythya nyroca (Anatidae) in Garaet Hadj Tahar (Guerbes-Sanhadja, Northeast of Algeria)," Zoology and Ecology, 2014.

[22] H. Azafzaf, “The Ferruginous Duck in Tunisia," in Ferruginous Duck: From Research to Conservation, N. Petkov, B. Hughes, and U. Gallo-Orsi, Eds., Conservation Series No6, Birdlife International-BSPB-TWSG, Sofia, Bulgaria, 2003.

[23] P. Isenmann, T. Gaultier, A. El Hili, H. Azafzaf, H. Dlensi, and M. Smart, Oiseaux de Tunisie, vol. 432, SEOF Editions, Paris, France, 2005.

[24] H. Azafaf, C. Feltrup-Azafzaf, H. Dlensi, and P. Isenmann, "Nouvelles données sur l'avifaune de Tunisie (2005-2014)," Alauda, vol. 83, no. 1, pp. 7-28, 2015.

[25] B. Samraoui and F. Samraoui, "An ornithological survey of Algerian wetlands: Important Bird Areas, Ramsar sites and threatened species," Wildfowl, vol. 58, pp. 71-96, 2008.

[26] R. Aissaoui, A. Tahar, M. Saheb, L. Guergueb, and M. Houhamdi, "Diurnal behavior of Ferruginous duck Aythya nyroca wintering at the El-Kala wetlands (Northeast Algeria)," Bulletin de l'Institut Scientifique, Rabat, section Sciences de la Vie, vol. 33, pp. 67-75, 2011.

[27] N. Baaziz, B. Mayache, M. Saheb et al., "Statut phénologique et reproduction des peuplements d'oiseaux d'eau dans l'écocomplexe de zones humides de Sétif (Hauts plateaux, Est de l'Algérie)," Bulletin de l'Institut Scientifique, Rabat, Section Sciences de la Vie, vol. 33, no. 2, pp. 77-87, 2011. 
[28] P. Isenmann and A. Moali, Les oiseaux d'Algérie, SEOF Editions, Paris, France, 2000.

[29] A. Djelailia, N. Baaziz, F. Samraoui, A. H. Alfarhan, and B. Samraoui, "Distribution and breeding ecology of the Ferruginous duck Aythya nyroca in Algeria," Ostrich, vol. 89, no. 1, pp. 5-12, 2018.

[30] H. Rizi, N. Ziane, R. Rouag, and M. S. Boulaakoud, "Evolution of the breeding population of the Ferruginous duck (Aythya nyroca, Güldenstädt, 1770) at Lake Tonga (Northeast of Algeria)," Journal of Entomology and Zoology Studies, vol. 4, no. 6, pp. 191-195, 2016.

[31] L. D. C. Fishpool and M. I. Evans, Important Bird Areas of Africa and Associated Islands: Priority Sites for Conservation, L. D. C. Fishpool and M. I. Evans, Eds., vol. 36, Pisces Publications/BirdLife International, Newbury/Cambridge, UK, 2001.

[32] F. Samraoui, A. H. Alfarhan, K. A. Al-Rasheid, and B. Samraoui, "An Appraisal of the Status and Distribution of Waterbirds of Algeria: Indicators of Global Changes?" Ardeola, vol. 58, no. 1, pp. 137-163, 2011.

[33] F. Ayaichia, F. Samraoui, N. Baaziz, N. Meziane, and B. Samraoui, "Sitting ducks: diet of wintering wildfowl in Lake Tonga, northeast Algeria," Wetlands Ecology and Management, pp. 1-13, 2017.

[34] F. Ramírez, C. Rodríguez, J. Seoane, J. Figuerola, J. Bustamante, and B. Yue, "How will climate change affect endangered Mediterranean waterbirds?” PLoS ONE, vol. 13, no. 2, p. e0192702, 2018.

[35] J. J. Purger and L. A. Mészáros, "Possible effects of nest predation on the breeding success of Ferruginous ducks Aythya nyroca," Bird Conservation International, vol. 16, no. 4, pp. 309316, 2006.

[36] B. Balmaki and A. Barati, "Harvesting Status of Migratory Waterfowl in Northern Iran: A Case Study from Gilan Province," in Waterbirds around the World, G. Boere, C. Galbraith, and D. Stroud, Eds., pp. 868-869, The Stationary Office, Edinburgh, UK, 2006.

[37] A.-L. Brochet, W. Van Den Bossche, S. Jbour et al., "Preliminary assessment of the scope and scale of illegal killing and taking of birds in the Mediterranean," Bird Conservation International, vol. 26, no. 1, pp. 1-28, 2016.

[38] Z. Nouaceur and O. Murărescu, "Rainfall variability and trend analysis of annual rainfall in North Africa," International Journal of Atmospheric Sciences, vol. 2016, Article ID 7230450, 12 pages, 2016.

[39] Z. Xumao and R. Maming, "The status of Ferruginous duck Ayhya nyroca breeding and wintering in China," Wildfowl, vol. 64, pp. 116-125, 2014.

[40] N. N. Berezovikov and I. F. Samusev, "The Ferruginous Duck in the upper reaches of the Irtysh river," Casarca, vol. 4, 1998.

[41] A. J. Green, M. E. Hamzaoui, M. A. El Agbani, and J. Franchimont, "The conservation status of Moroccan wetlands with particular reference to waterbirds and to changes since 1978," Biological Conservation, vol. 104, no. 1, pp. 71-82, 2002. 


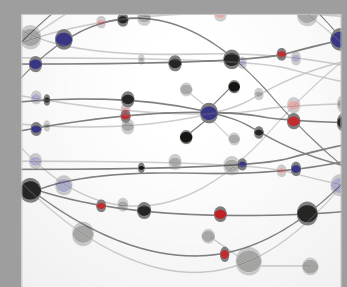

The Scientific World Journal
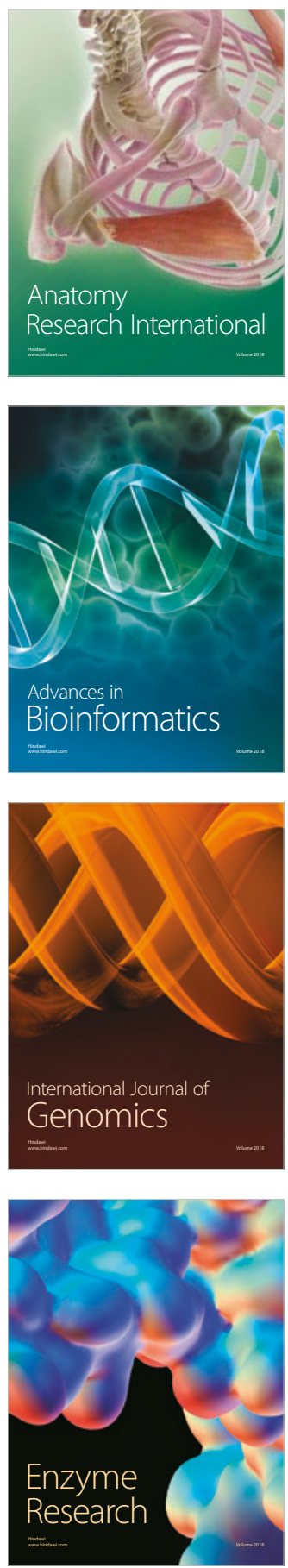
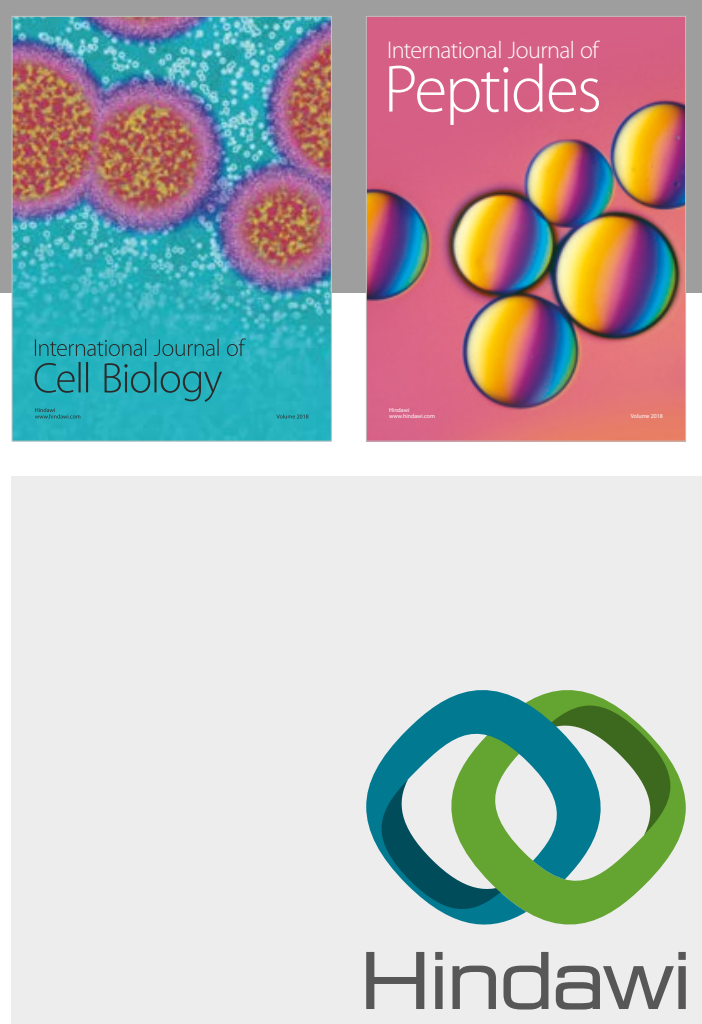

Submit your manuscripts at

www.hindawi.com
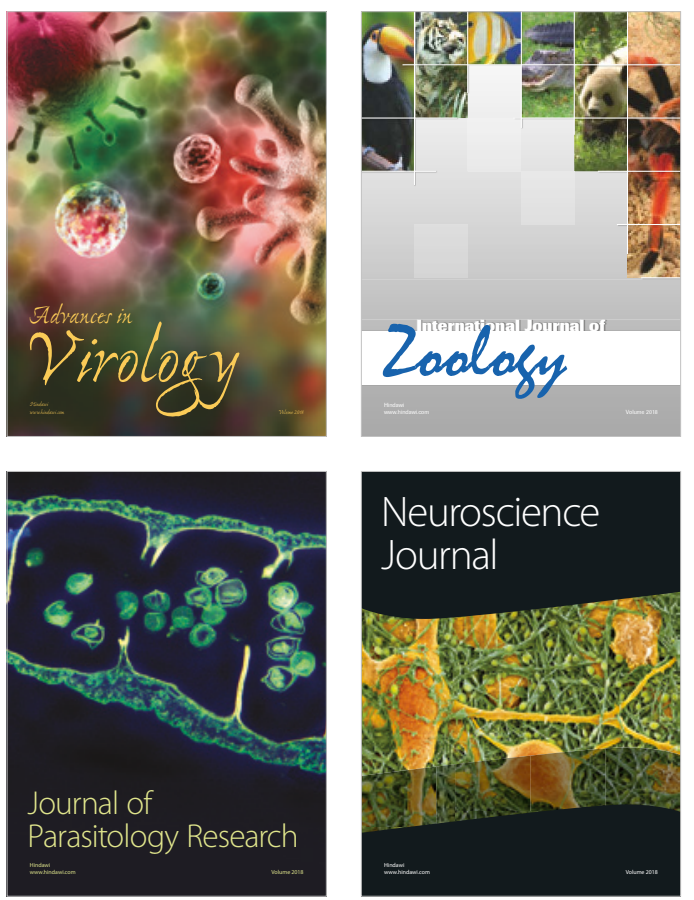
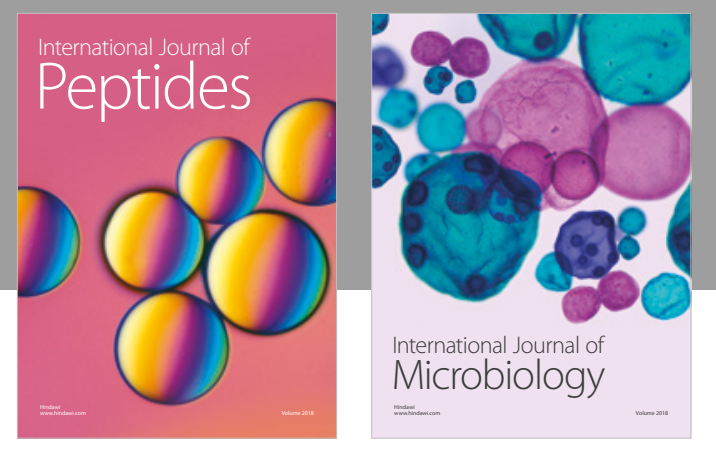

nternational Journal of Microbiology
Journal of
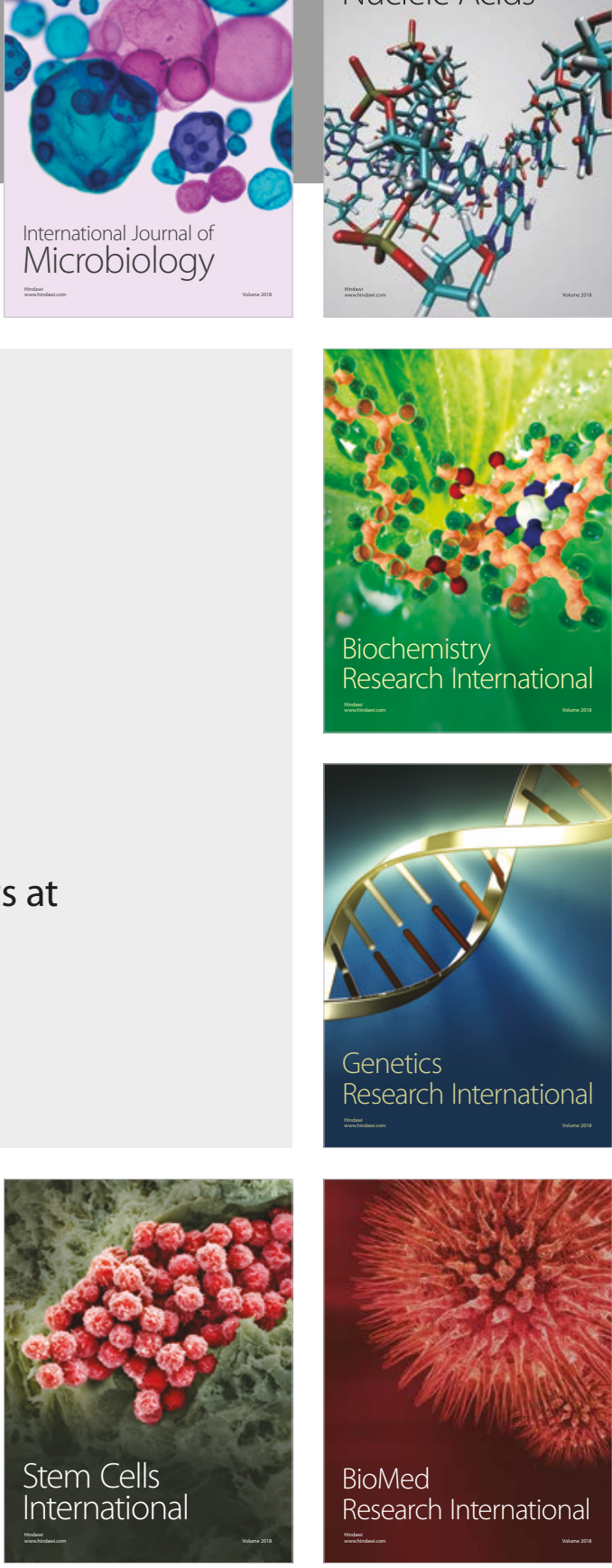
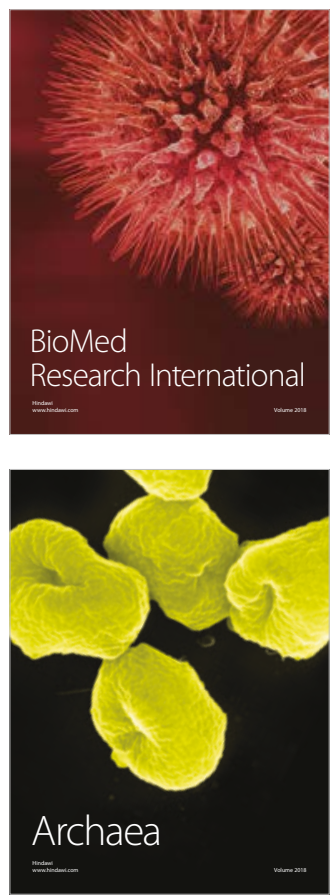